\author{
Asian Journal of \\ Medical and Biological Research \\ ISSN 2411-4472 (Print) 2412-5571 (Online) \\ www.ebupress.com/journal/ajmbr
}

\title{
Article \\ Effect of water parameters on temporal distribution and abundance of zooplankton at Kaptai lake reservoir, Rangamati, Bangladesh
}

Md. Anowarul Haque ${ }^{1}$, Md Rashed-Un-Nabi ${ }^{1}$, Md Masum Billah ${ }^{1,2,3 *}$, Abdulla-Al-Asif ${ }^{4,5}$, Mohammed Rezowan ${ }^{1}$, Md. Atiqul Islam Mondal ${ }^{1}$, Abdullah Al Mamun Siddiqui ${ }^{1}$, Syed Shoeb Mahmud ${ }^{1}$ and Md. Razon $\mathrm{Khan}^{1,3}$

${ }^{1}$ Institute of Marine Sciences and Fisheries, University of Chittagong, Chittagong - 4331, Bangladesh

${ }^{2}$ Department of Land Management, Faculty of Agriculture, Universityi Putra Malaysia, 43400 UPM, Serdang, Selangor Darul Ehsan, Malaysia

${ }^{3}$ Department of Environmental Conservation, School of Science, University of Greenwich, Medway Campus, Chatham Maritime, Kent ME4 4TB, United Kingdom

${ }^{4}$ Department of Fisheries and Marine Bioscience, Faculty of Biological Science and Technology, Jessore University of Science and Technology, Jessore-7408, Bangladesh

${ }^{5}$ Department of Aquaculture, Faculty of Fisheries, Bangladesh Agricultural University, Mymensingh-2202, Bangladesh

*Corresponding author: Md Masum Billah, Department of Environmental Conservation, School of Science, University of Greenwich, Medway Campus, Chatham Maritime, Kent ME4 4TB, United Kingdom. Phone: +8801762291455; E-mail: billahims@yahoo.com

Received: 07 December 2018/Accepted: 27 December 2018/ Published: 30 December 2018

Abstract: Seasonal abundance of zooplankton in relation to different physico-chemical conditions of Kaptai lake has been studied. A total of four major groups of zooplankton were identified from study area of Kaptai lake during three seasons observation at pre-monsoon, monsoon and Post-monsoon. These four groups were categorized into rotifers, copepods, cladocerans and others (fish larvae, shrimp larvae, insects, mosquito larvae etc.). The mean abundance of group rotifers, copepods, cladoceras and others were 103,84.67, 38.33 and 41.83 ind. $\mathrm{L}^{-1}$ respectively. The highest group was rotifers in terms of abundance and composition where compositions were recorded $38 \%$ at three season's observation. The lowest group was cladoceras in term of abundance and composition where compositions were recorded $14 \%$. The air temperature, water temperature, transparency, water $\mathrm{pH}, \mathrm{DO}, \mathrm{BOD} 5, \mathrm{PO}_{4}-\mathrm{P}, \mathrm{NO}_{2}-\mathrm{N}, \mathrm{SiO}_{3}-\mathrm{Si}$, TSS, TDS, Alkalinity ranged between 21 and $27.5^{\circ} \mathrm{C}, 23.5$ and $31.5^{\circ} \mathrm{C}, 0.8$ and $3 \mathrm{~m}, 7.1$ and $7.5,5.72$ and $8.58 \mathrm{mg} / \mathrm{l}, 8.55$ and $12.87 \mathrm{mg} / \mathrm{l}, 3.22$ and $4.13 \mu \mathrm{g} / \mathrm{l}, 0.992$ and 1.19 $\mu \mathrm{g} / \mathrm{l}, 161.18$ and $201.15 \mu \mathrm{g} / \mathrm{l}, 0.28$ and $0.48 \mathrm{~g} / \mathrm{l}, 0.18$ and $0.68 \mathrm{~g} / \mathrm{l}, 40$ and $60 \mathrm{ppm}$, respectively. Margalef richness index (d), Pielou's evenness index $\left(\mathrm{J}^{\prime}\right)$, Shannon-Wiener diversity index $\left(\mathrm{H}^{\prime}\right)$, Simpson dominance index $(\lambda)$ are analyzed by Primer V6 software to quantify the collected species. Through same software SIMPER, Cluster analysis also done to compare similarity between season.

Keywords: distribution; abundance; zooplankton; Kaptai lake

\section{Introduction}

The Lake Kaptai was created by damming the river Karnafully near Kaptai town in the Chittagong Hill Tracts (Lat. $22^{\circ} 29^{\prime}$ and Long. $92^{\circ} 17^{\prime}$ E). The Dam was completed and spillway was closed in May, 1961. Occupying an average area of 58,300 ha (ARG, 1986), it is one of the largest reservoirs in Southeast Asia (Farnando, 1980). Although the lake was created primarily for hydro-electrical power generation, it has also paved the way for substantial contribution to the national economy through freshwater fish production, navigation, irrigation and flood control. The Inland open water (capture) fish production of Bangladesh is 1,123,925 Mt (2008-2009). 
Kaptai lake comprises about 8,590 Mt and catch/area is $125 \mathrm{~kg} / \mathrm{ha}$ (DoF, 2010). Based on 24 years of records obtained from the Bangladesh Power Development Authority, the average annual surface area of the reservoir is 58,300 hectors $(144,000$ acres $)$, the mean depth is 9 meters $(29.5$ feet), and the water exchange rate is about three times per year and the water level fluctuations vertically 8.1 meters ( 26.5 feet) per year. In water flow ecosystem, factors like the temperature, concentration of nutrients, oxygen, water flow, light, carbon dioxide, ammonia, pH played plethora impact (Islam et al., 2017). The knowledge on the abundance, composition and seasonal succession of the planktonic organisms is an essential prerequisite for the successful management of an aquatic eco-system of Kaptai Lake. Zooplankton abundance and distribution are an index to the diversity of an area and provides information of an ecosystem. It is well recognized that the richest fisheries of the world are closely related to the plankton production because fishery and other organisms are directly depends on plankton for their food. Kaptai Lake carries large amounts of nutrients and facilitates the production of large quantities of plankton in the area. With an intimate knowledge of zooplankton abundance, composition in space and time, it should be possible to direct fishery exploitation to the right place at the right time. Zooplankton contains a huge reservoir of concentrated vitamin A which is also important to increase the production of the fish species. It plays a vital role in food chain of Lake Ecosystem. It comprises the $2^{\text {nd }}$ and $3^{\text {rd }}$ tropic level of the food chain which known as primary and secondary consumers. These zooplanktons are further consumed by tertiary consumers of the food chain. Thus zooplankton increases the production of the fisheries resources. By grazing more phytoplankton zooplankton keeps the lake from bloom formation. On the other hand zooplankton releases $\mathrm{CO}_{2}$ during their respiration. The released $\mathrm{CO}_{2}$ is very essential element of the primary production through photosynthesis. Thus zooplankton maintains the relationship between the primary producers and tertiary consumers and balance the ecosystem of the lake ultimately increase the production of fish species. The zooplankton consists of those planters with a holozoic nutrition, and thus it includes all the planktonic animals (Wickstead, 1965). Bangladesh is a tropical to subtropical country. Variation of physico-chemical parameter occurs in monthly or seasonally. There are four types of seasonal variation occurs in Bangladesh, namely Postmonsoon, pre-monsoon, monsoon, post monsoon (Mahmood et al., 1976). A marked seasonal fluctuation in salinity, dissolved oxygen, water temperature and suspended particle is very common in Bangladesh (Akther, 2018). Tropical water is very rich with a variety of aquatic life; Bangladesh is not an exception of that (West, 1973). In Bangladesh, the peak abundance of zooplankton is normally observed during Post-monsoon and premonsoon season (Elais, 1983) when the water transparency range between $66 \mathrm{~cm}$ to $77.5 \mathrm{~cm}$. The relatively lower zooplankton is observed during monsoon period, when the water transparency range between $17.5 \mathrm{~cm}$ and $38.0 \mathrm{~cm}$. However, the dependent on the different location as stated by Zafar (1986). The water level fluctuates appreciably throughout the year in Kaptai Lake. Wide seasonal fluctuations were also noted in water transparency. The lake was found to be slightly hard and alkaline pH. Dissolved Oxygen (DO) (6.4-9.1 mg/l) contents showed favorable condition for aquatic lives. The direct correlation between zoo and phytoplankton was reported by Ayyappan and Gupta (1980). Contrary to it, Khan and Sidiqui (1974) showed an inverse relation between themselves. Elser and Goldman (1991) established no significant correlation between phyto and zooplankton. He showed that most of the physico-chemical factors correlate to the zooplankton abundance at least to a certain extent. Since independent effects of a few chemicals factors on the phytoplankton were found significant. It may be assumed that the seasonal abundance of phytoplankton in Kaptai Lake is mostly controlled by a few chemical factors and on the other hand, seasonal abundance of zooplankton almost controlled by combination of various factors. The present study is conducted to investigate the temporal distribution, abundance and composition of some major zooplankton in Kaptai Lake reservoir and to study the relationship of Zooplankton with environmental parameters.

\section{Materials and Methods}

\subsection{Location of the study area}

This study was conducted at pre-monsoon (May'10), monsoon (August'10) and post-monsoon (November'10) in the Kaptai reservoir (Lat. $22^{\circ} 20^{\prime}-23018^{\prime}$ N, Long. $92^{\circ} 00^{\prime}-92^{\circ} 26^{\prime}$ E) at Rangamati Paurashava in Rangamati Sadar upazilla under the Rangamati district.

\subsection{Collection of samples}

\subsubsection{Sampling season}

The sampling was carried out according to this weather pattern in the month of May (pre-monsoon) and August (rainy season or monsoon) and November (post-monsoon), 2010 from the studied area. 


\subsection{Data collection}

Sampling was done primarily by means of field observation and collection of samples, secondarily by laboratory analysis to determine the abundance and composition of zooplankton and water quality parameters of Kaptai Lake during the study period at Pre-Monsoon (May'10), Monsoon (August'10) and Post-monsoon (November'10). The required data (map of study area or upazilla with union boundary, research articles or secondary data etc.) were collected from different department (FRI and BFDC, University etc.).

\subsubsection{Data of primary source}

Data of primary source were collected by direct observation in the field, collecting samples and laboratory analysis of samples and some selected ecological and water quality parameters of the selected sites.

\subsubsection{Data of secondary source}

Base map and land use data of the study area, subject wise relevant documents and reports were also collected to validate the field observation.

\subsection{In situ determination of water parameters}

The surface water temperature was recorded by the help of a graduated centigrade thermometer $\left({ }^{\circ} \mathrm{C}\right)$. Hydrogen Ion Concentration was determined by using a digital $\mathrm{pH}$ meter and transparency of water was recorded by a Secchi disc (30 cm diameter).

\subsection{Ex situ determination of water parameters}

2.5.1. Analysis of dissolved oxygen of water (DO)

From the collected water samples DO was detected by Azide modification of Winkler's methods using DO test kit (Water Quality Test Kit Instruction Manual, Code 5860-01) (Lind, 1979; LaMotte Company, 2011).

\subsubsection{Determination of BOD}

For determining the BOD5 of a particular sample, two BOD bottles are filled with given sample by using BOD meter (HQ40D Portable Biochemical Oxygen Demand (BOD) Meter) (Hach, 2010). At first the dissolved oxygen for one BOD bottle is calculated. Other is remained in dark condition for five days. After 5 days the D.O for the dark bottle is determined. In this way, the BOD level of a given sample for five days is determined from the difference between initial and final DO.

\subsubsection{Analysis of nitrite nitrogen $\left(\mathrm{NO}_{2}-\mathrm{N}\right)$}

This was analyzed by using Nitrite Nitrogen test kit (Thermo Fisher Scientific Company, 2004) through standard methods 4500-NO2-B Colorimetric Method (American Public Health Association, 1998), and in EPA method 354.1 (EMSL-Ci, 2003) to determine nitrite ion in waters as well as Nitrite nitrogen the following method - (APHA, 1976).

\subsubsection{Analysis of water nutrient phosphate-phosphorus $\left(\mathrm{PO}_{4}-\mathrm{P}\right)$}

This was analyzed by using Molybdenum blue method and with the help of phosphorus meter (On-site analyzer P 700 IQ) (WTW, 2003).

\subsubsection{Analysis of silicate-silicon $\left(\mathrm{SiO}_{3}\right.$-Si) of water sample}

This was analyzed by using the following method - (APHA, 1976).

\subsubsection{Determination of TSS of a water sample}

This was analyzed by using the following methods and procedure (Module, 1999).

\subsubsection{Determination of TDS of a water sample.}

This was analyzed by using the following method methods and procedure (Module, 1999).

\subsubsection{Determination of water alkalinity}

This was analyzed by using the following method - (APHA, 1976) and using alkalinity test kit (Thermo Fisher Scientific Company, 2008). 
2.5.9. Determination of water $\mathrm{pH}$

Water pen $\mathrm{pH}$ meter (Model- Micro Direct $\mathrm{pH} 10$ ) was used to determine the water $\mathrm{pH}$ in the field.

\subsection{Zooplankton sampling and analyses}

Sampling of water samples for zooplankton analyses was done on ten-liter water samples sampled from different areas and depths of the lake and filtered through $25 \mu$ mesh plankton net. Samples were collected at 3 season at Pre-monsoon (May'10), Monsoon (August'10) and Post-monsoon (November'10). Collected samples were transferred to container, labeled and marked with date and place of collection.

\subsection{Sample preservation}

Preservation of the samples before analyses was done by addition of 5\% buffered formalin in small plastic bottles and then transferred to the laboratory of IMSF-CU for analysis.

\subsection{Laboratory analysis}

\subsubsection{Settlement of samples}

Before analysis, the samples were allowed to settle in a $100 \mathrm{ml}$ cylinder and the overlying water containing floating plankton and other undesirable foreign particles were taken out.

\subsubsection{Staining and sorting}

For efficient sorting, the samples were stained with Rose Bengal and left for overnight. All the zooplankton would attain pink color rendering easy identification.

The stained zooplankton was them placed into different Petri-dishes and preliminary sorting of easily identifiable organisms was done by naked eyes using fine brush, needle, forceps and sometimes with magnifying glass. But for the analysis of minute organisms of different taxonomic groups, samples were observed under microscope. After sorting, the specimens were washed with distilled water and placed into different labeled vials having $70 \%$ alcohol for further analysis.

\subsection{Identification and counting}

The sorted zooplankton were brought under microscope and identified. The mean number of zooplankton was recorded and expressed numerically perliter of water of the lake.

\subsection{Data analysis}

\subsubsection{Species diversity analysis}

Diversity of the species assemblage was expressed by the Shannon-Wiener index (H') (Simpson, 1949; Shannon and Weaver, 1949), richness was measured by Margalef index (d) (Margalef, 1968), evenness was measured by Pielou's index (j) (Pielou, 1966) and dominance was measured by Simpson index (c) (Simpson, 1949).

\subsubsection{Statistical analysis}

The statistical analysis of different physic-chemical and zooplankton parameters were carried out by the statistical package of Primer 6, SPSS 11.5 while the Microsoft excel 2003 was used to plots graphs for dissemination of the results. The results of the physic-chemical parameters were expressed as mean $\pm \mathrm{SD}$. For environmental parameters (Air temperature, Water temperature, transparency, $\mathrm{pH}, \mathrm{DO}, \mathrm{BOD}_{5}, \mathrm{PO}_{4}-\mathrm{P}_{2} \mathrm{NO}_{2}-\mathrm{N}, \mathrm{Si}_{-} \mathrm{Sio}_{3}$, TDS, TSS and Alkalinity) Canonical Correspondence Analysis was used to calculate if there is any relationship among seasons. One way analysis of variance (ANOVA) was used to determine significant differences between seasons. Similarity percentage analyses (SIMPER) (Clarke, 1993) was used to observe the percentage contribution of each species to he average dissimilarity between samples of the various season. Hierarchial agglomerative clustering with group average linking was performed to investigate similarities among seasons (Clarke and Warwick, 1994). This test is based on a Bray-Curtis rank similarity matrix (Bray and Curtis, 1957) and were calculated using $\log$ transformed data $(\log (X+1)$. All the bivariate and multivariate analyses were performed using the software PRIMER v6.

\section{Result}

\subsection{Environmental variables}

\subsubsection{Air temperature}

The air temperature varied from $21^{\circ} \mathrm{C}$ to $-27.5^{\circ} \mathrm{C}$ with a mean value of $25.17 \pm 1.07^{\circ} \mathrm{C}$ in the study area (Table 1 ). Lowest value observed in post-monsoon while the highest value observed in pre-monsoon. 


\subsubsection{Water temperature}

Water temperature in the study area varied from $23.5^{\circ} \mathrm{C}$ to $31.5^{\circ} \mathrm{C}$ with a mean value of $28.17 \pm 1.13^{\circ} \mathrm{C}$ (Table 1 ). Lowest value observed in post-monsoon; highest value observed in monsoon.

\subsubsection{Water $\mathrm{pH}$}

Water $\mathrm{pH}$ in the study area varied from 7.1 to 7.5 with a mean value of $7.27 \pm 0.34$ (Table 1). Lowest value observed in post-monsoon; highest value observed in monsoon.

\subsubsection{Water transparency}

Water transparency in the study area varied from $0.8 \mathrm{~m}$ to $3 \mathrm{~m}$ with a mean value of $1.80 \pm 0.33 \mathrm{~m}$ (Table 1 ). Lowest value observed in pre-monsoon; highest value observed in monsoon.

\subsubsection{Dissolve oxygen (D.O.)}

Dissolve oxygen in the study area varied from $5.72 \mathrm{mg} / \mathrm{L}$ to $8.58 \mathrm{mg} / \mathrm{L}$ with a mean value of $7.15 \pm 0.39 \mathrm{mg} / \mathrm{L}$ (Table 1). Lowest value observed in pre-monsoon; highest value observed in monsoon.

\subsubsection{Biological Oxygen Demand after 5 days $\left(\mathrm{BOD}_{5}\right)$}

Biological Oxygen Demand after 5 days in the study area varied from $8.55 \mathrm{mg} / \mathrm{L}$ to $12.87 \mathrm{mg} / \mathrm{L}$ with a mean value of $10.00 \pm 0.68 \mathrm{mg} / \mathrm{L}$ (Table 1). Lowest value observed in post-monsoon; highest value observed in premonsoon.

\subsubsection{Phosphate-phosphorus $\left(\mathrm{PO}_{4}-\mathrm{P}\right)$}

$\mathrm{PO}_{4}-\mathrm{P}$ in the study area varied from $3.22 \mu \mathrm{g} / \mathrm{L}$ to $4.13 \mu \mathrm{g} / \mathrm{L}$ with a mean value of $3.67 \pm 0.15 \mu \mathrm{g} / \mathrm{L}$ (Table 1 ). Lowest value observed in pre-monsoon; highest value observed in post-monsoon.

\subsubsection{Nitrite-nitrogen $\left(\mathrm{NO}_{2}-\mathrm{N}\right)$}

$\mathrm{NO}_{2}-\mathrm{N}$ in the study area varied from $0.992 \mu \mathrm{g} / \mathrm{L}$ to $1.19 \mu \mathrm{g} / \mathrm{L}$ with a mean value of $1.09 \pm 0.19 \mu \mathrm{g} / \mathrm{L}$ (Table 1 ). Lowest value observed in monsoon; highest value observed in post-monsoon.

\subsubsection{Silicate-silicon $\left(\mathrm{Si}_{-} \mathrm{SiO}_{3}\right)$}

$\mathrm{Si}_{-} \mathrm{SiO}_{3}$ in the study area varied from $161.18278 .34 \mu \mathrm{g} / \mathrm{L}$ to $201.15 \mu \mathrm{g} / \mathrm{L}$ with a mean value of $183.46 \pm 10.72$ $\mu \mathrm{g} / \mathrm{L}$ (Table 1). Lowest value observed in pre-monsoon; highest value observed in post-monsoon.

\subsubsection{Total suspended solid (TSS)}

TSS in the study area varied from $0.28 \mathrm{~g} / \mathrm{L}$ to $0.48 \mathrm{~g} / \mathrm{L}$ with a mean value of $0.37 \pm 0.06(\mathrm{~g} / \mathrm{l})$ (Table 1$)$. Lowest value observed in post-monsoon; highest value observed in monsoon.

\subsubsection{Total dissolve solid (TDS)}

TDS in the study area varied from $0.18 \mathrm{~g} / \mathrm{L}$ to $0.68 \mathrm{~g} / \mathrm{L}$ with a mean value of $0.39 \pm 0.02 \mathrm{~g} / \mathrm{L}$ (Table 1 ). Lowest value observed in post-monsoon; highest value observed in monsoon.

\subsubsection{Alkalinity}

Alkalinity in the study area varied from $40 \mathrm{ppm}$ to $60 \mathrm{ppm}$ with a mean value of $50.00 \pm 6.47 \mathrm{ppm}$ (Table 1). Lowest value observed in monsoon; highest value observed in post-monsoon.

\subsection{Species abundance}

In the Kaptai lake a total of four groups consisting of rotifers, copepods, cladoceras and others (fish larvae, shrimp larvae, insects, mosquito larvae etc.) were collected during the study. They represent 9 classes belonging to 3 groups (Table 2). The most dominant group was found to be rotifers (4 class; Brachionus, Asplanchna. Keratella, Filinia) followed by copepods (2 class; Diaptomus, Cyclops), cladoceras (3 class; Daphnia, Moina, Diaphanosoma), and other minor groups are categorized into group; others. The group others consist of different types of larvae (fish, shrimp, mosquito etc.) and insects. The most dominant taxa was found to be cyclops (18\%) followed by Diaptomus (14\%), Brachionus (12\%), Asplanchna (10\%) (Table 2). The major groups abundance was found as rotifers- $112 \mathrm{indv} / \mathrm{l}$ (pre-monsoon), $104 \mathrm{indv} / \mathrm{l}$ (monsoon) and $93 \mathrm{indv} / \mathrm{l}$ (postmonsoon), copepods- $98 \mathrm{indv} / \mathrm{l}$ (pre-monsoon), $84 \mathrm{indv} / \mathrm{l}$ (monsoon), $72 \mathrm{indv} / 1$ (post-monsoon), cladoceras- 43.5 indv/l (pre-monsoon), $37 \mathrm{indv} / \mathrm{l}$ (monsoon) and $34.5 \mathrm{indv} / \mathrm{l}$ (post-monsoon) and others- $47 \mathrm{indv} / \mathrm{l}$ (pre-monsoon), 
$42.5 \mathrm{indv} / \mathrm{l}$ (monsoon) and $41 \mathrm{indv} / \mathrm{l}$ (post-monsoon) (Figure 1). The species abundance per liter ranged between 4.81 individual/litre (in post-monsoon) to 6.01 individual/liter (in pre-monsoon) with an average of 5.39 \pm 3.14 individual/liter (Table 3).

Table 1. Water Quality Parameters at three seasons (Pre-monsoon, Monsoon and Post-monsoon) with standard deviation.

\begin{tabular}{llllll}
\hline Parameters & Pre-monsoon & Monsoon & Post-monsoon & Mean & Range \\
\hline Air Temp. $\left({ }^{\mathbf{C}} \mathbf{C}\right)$ & $27.50 \pm 00.70$ & $27.00 \pm 01.20$ & $21.00 \pm 01.30$ & $25.17 \pm 1.07$ & $21.00-27.50$ \\
Water Temp. $\left({ }^{\mathbf{0}} \mathbf{C}\right)$ & $29.50 \pm 01.10$ & $31.50 \pm 00.80$ & $23.50 \pm 01.50$ & $28.17 \pm 1.13$ & $23.50-31.50$ \\
pH & $07.20 \pm 0.35$ & $07.50 \pm 00.43$ & $07.10 \pm 00.25$ & $7.27 \pm 0.34$ & $07.10-07.50$ \\
Transparency $(\mathbf{m})$ & $01.60 \pm 00.25$ & $00.80 \pm 00.45$ & $03.00 \pm 00.30$ & $1.80 \pm 0.33$ & $00.80-03.00$ \\
DO $(\mathbf{m g} / \mathbf{l})$ & $05.72 \pm 00.35$ & $08.58 \pm 00.55$ & $07.14 \pm 00.28$ & $7.15 \pm 0.39$ & $05.72-08.58$ \\
$\mathbf{B O D 5}(\mathbf{m g} / \mathbf{l})$ & $12.87 \pm 00.48$ & $08.58 \pm 01.20$ & $08.55 \pm 00.35$ & $10.00 \pm 0.68$ & $08.55-12.87$ \\
$\mathbf{P O}_{\mathbf{4}}-\mathbf{P}(\boldsymbol{\mu g} / \mathbf{l})$ & $03.22 \pm 00.15$ & $03.67 \pm 00.12$ & $04.13 \pm 00.18$ & $3.67 \pm 0.15$ & $03.22-04.13$ \\
$\mathbf{N O}_{\mathbf{2}}-\mathbf{N}(\boldsymbol{\mu g} / \mathbf{l})$ & $01.10 \pm 00.23$ & $00.99 \pm 00.18$ & $01.19 \pm 00.15$ & $1.09 \pm 0.19$ & $00.99-01.19$ \\
$\mathbf{S i O}_{\mathbf{3}}-\mathbf{S i}(\boldsymbol{\mu g} / \mathbf{l})$ & $161.18 \pm 12.40$ & $188.04 \pm 09.50$ & $201.15 \pm 10.25$ & $183.46 \pm 10.72$ & $161.18-201.15$ \\
$\mathbf{T S S}(\mathbf{g} / \mathbf{l})$ & $00.35 \pm 00.06$ & $00.48 \pm 00.08$ & $00.28 \pm 00.05$ & $0.37 \pm 0.06$ & $00.28-00.48$ \\
TDS $(\mathbf{g} / \mathbf{l})$ & $00.31 \pm 00.03$ & $00.68 \pm 00.02$ & $00.18 \pm 00.02$ & $00.39 \pm 00.02$ & $00.18-00.68$ \\
Alkalinity (ppm) & $50.00 \pm 07.50$ & $40.00 \pm 06.40$ & $60.00 \pm 05.50$ & $50.00 \pm 06.47$ & $40.00-60.00$ \\
\hline
\end{tabular}

Table 2. Distribution, abundance and composition of Zooplankton at Premonsoon, Monsoon and Postmonsoon.

\begin{tabular}{|c|c|c|c|c|}
\hline Group & Class & $\begin{array}{l}\text { Premonsoon } \\
\text { (indv/l) }\end{array}$ & $\begin{array}{l}\begin{array}{l}\text { Monsoon } \\
\text { (indv/l) }\end{array} \\
\end{array}$ & $\begin{array}{l}\text { Post-monsoon } \\
\text { (indv/l) }\end{array}$ \\
\hline \multirow{5}{*}{ 苋 } & Brachionus & 37 & 37 & 25.5 \\
\hline & Asplanchna & 29 & 25 & 24 \\
\hline & Keratella & 37.5 & 24 & 22.5 \\
\hline & Filinia & 8.5 & 18 & 21 \\
\hline & Total & 112 & 104 & 93 \\
\hline \multirow{3}{*}{ 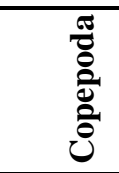 } & Diaptomus & 43 & 39 & 33 \\
\hline & Cyclops & 55 & 45 & 39 \\
\hline & Total & 98 & 84 & 72 \\
\hline \multirow{4}{*}{ 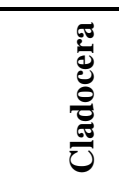 } & Daphnia & 15 & 14.5 & 13 \\
\hline & Moina & 14.5 & 9 & 8 \\
\hline & Diaphanosoma & 14 & 13.5 & 13.5 \\
\hline & Total & 43.5 & 37 & 34.5 \\
\hline Others & $\begin{array}{l}\text { Fish, shrimp, mosquito larvae, } \\
\text { insects etc. }\end{array}$ & 47 & 42.5 & 41 \\
\hline
\end{tabular}

Table 3. Occurrence of major Zooplankton groups at different seasons and percentage of abundance at those seasons.

\begin{tabular}{lllll}
\hline Occurrence of Zooplankton & Rotifera & Copepoda & Cladocera & Others \\
\hline Pre-monsoon (indv/l) & 112 & 98 & 43.5 & 47 \\
Pre-monsoon (\%) & 37 & 33 & 14 & 16 \\
Monsoon (indv/l) & 104 & 84 & 37 & 42.5 \\
Monsoon (\%) & 39 & 31 & 14 & 16 \\
Post-monsoon (indv/l) & 93 & 72 & 34.5 & 36 \\
Post-monsoon (\%) & 39 & 31 & 15 & 15 \\
Total (\%) & 38 & 32 & 14 & 16 \\
\hline
\end{tabular}




\subsection{Species diversity}

\subsubsection{Margalef richness index (d)}

The minimum Margalef richness index was observed at pre-monsoon (3.069), while highest value observed in post-monsoon (3.128) (Table 4) with mean richness value of $3.10 \pm 0.030$.

\subsubsection{Pielou's evenness index $\left(\mathrm{J}^{\prime}\right)$}

Pielou's evenness index was found minimum at pre-monsoon (0.985) and maximum value observed at postmonsoon (0.990) (Table 4) with mean value of $0.99 \pm 0.003$.

\subsubsection{Shannon-Wiener diversity index $\left(\mathrm{H}^{\prime}\right)$}

The Shannon-Wiener diversity index $\left(\mathrm{H}^{\prime}\right)$ ranged from 2.268 (at pre-monsoon) to 2.280 (post-monsoon) (Table 4) with mean diversity value of $2.27 \pm 0.006$.

\subsubsection{Simpson dominance index (c)}

The minimum value of Simpson dominance index was observed at pre-monsoon (0.944) and maximum value was observed at pre-monsoon (0.949) (Table 4) with mean value of $0.95 \pm 0.003$.

Table 4. Different diversity index measured at Kaptai Lake reservoir.

\begin{tabular}{lllll}
\hline Seasons (Sample) & $\begin{array}{l}\text { Margalef richness } \\
\text { index }(\mathbf{d})\end{array}$ & $\begin{array}{l}\text { Pielou's evenness } \\
\text { index }\left(\mathbf{J}^{\prime}\right)\end{array}$ & $\begin{array}{l}\text { Shannon-Wiener } \\
\text { diversity index }\left(\mathbf{H}^{\prime}\right)\end{array}$ & $\begin{array}{l}\text { Simpson dominance } \\
\text { index }(\mathbf{c})\end{array}$ \\
\hline Pre-monsoon & 3.069 & 0.985 & 2.268 & 0.944 \\
Monsoon & 3.110 & 0.988 & 2.276 & 0.947 \\
Post-monsoon & 3.128 & 0.990 & 2.280 & 0.949 \\
\hline
\end{tabular}

\subsection{Species assemblage}

\subsubsection{SIMPER analysis}

SIMPER analysis shows the pair-wise average similarity or dissimilarity of species in pre-monsoon and monsoon, pre-monsoon and post-monsoon and monsoon and post-monsoon season. The average dissimilarity of pre-monsoon and Monsoon is 4.73, pre-monsoon and post-monsoon is 6.56 and monsoon and post-monsoon is 1.83. In this pair-wise combination, the monsoon and post-monsoon season have shown the highest similarity (98.17\%); while in pre-monsoon and monsoon season and pre-monsoon and post-monsoon season have 95.27 and $93.44 \%$ respectively (Table 5).

Table 5. Average similarity and discriminating of species in each seasons using SIMPER analysis.

\begin{tabular}{|c|c|c|c|c|c|}
\hline \multicolumn{2}{|c|}{ Pre-monsoon and Monsoon } & \multicolumn{2}{|c|}{ Pre-monsoon and Post-monsoon } & \multicolumn{2}{|c|}{ Monsoon and Post-monsoon } \\
\hline \multicolumn{2}{|c|}{ Average dissimilarity: 4.73} & \multicolumn{2}{|c|}{ Average dissimilarity: 6.56} & \multicolumn{2}{|c|}{ Average dissimilarity: 1.83} \\
\hline Species & Contribution (\%) & Species & Contribution (\%) & Species & Contribution (\%) \\
\hline Filinia & 29.34 & Filinia & 28.91 & Brachionus & 38.26 \\
\hline Keratella & 23.29 & Keratella & 16.91 & Filinia & 27.76 \\
\hline Moina & 16.52 & Cyclops & 12.00 & Diaptomus & 17.93 \\
\hline Cyclops & 10.47 & Moina & 12.00 & Cyclops & 16.04 \\
\hline Asplanchna & 8.85 & Brachionus & 10.48 & & \\
\hline Diaptomus & 6.05 & Diaptomus & 09.31 & & \\
\hline & & Asplanchna & 06.43 & & \\
\hline
\end{tabular}

\subsubsection{Cluster analysis}

Cluster analysis shows distinct separation between seasons. At the similarity level of $96 \%$ two cluster groups are attained. Both cluster groups contains 2 samples each (Figure 2). 


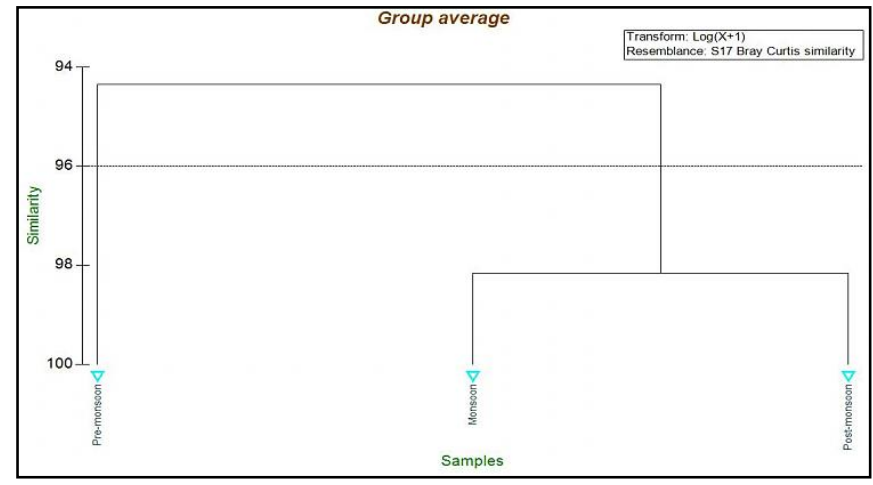

Figure 2. Dendrogram showing cluster based on Bray-Curtis similarity matrix of different stations and seasons.

\subsubsection{Canonical correspondence analysis}

The CCA (Canonical Correspondence Analysis) ordination of species abundance and water parameters are given in figure 3.

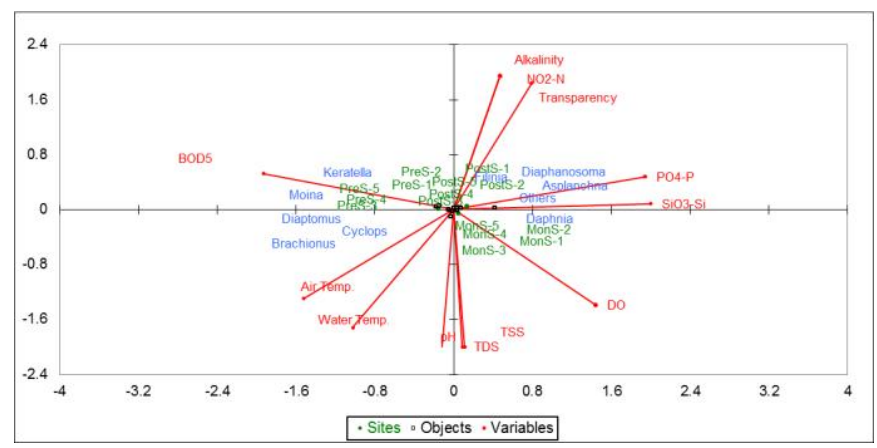

Figure 3. The CCA (Canonical Correspondence Analysis) ordination of species abundance and water parameters.

\section{Discussion}

The Environmental parameters like temperature, dissolved oxygen, biological oxygen demand, water transparency, $\mathrm{pH}, \mathrm{PO}_{4}-\mathrm{P}, \mathrm{NO}_{2}-\mathrm{N}, \mathrm{SiO}_{3}-\mathrm{Si}$, TSS, TDS, Alkalinity etc. play an important role for species abundance and diversity (Whitfield,1999) specially for the tropical regions where the fluctuation of these parameters are very frequent due to changes in seasons (Blaber, 2000). The largest man-made lake of the country; Kaptai is not exception of that. Significant $(p<0.05)$ temporal differences were observed for those parameters during the study. Though Chittagong Hill Tracts is a hilly region no special weather condition was noticed. Only in winter months, sometimes morning fog and heavy dew were observed and in monsoon, occasionally gusty wind prevails in this area (Akther, 2018). The maximum air temperature $\left(27.50 \pm 0.70^{\circ} \mathrm{C}\right)$ in pre-monsoon and water temperature $\left(31.5 \pm 0.80^{\circ} \mathrm{C}\right)$ in monsoon was recorded while minimum air temperature $\left(21.00 \pm 1.30^{\circ} \mathrm{C}\right)$ in post-monsoon and minimum water temperature $\left(23.5 \pm 1.50^{\circ} \mathrm{C}\right)$ in post-monsoon was recorded and similar season wise temperature change observation was conducted by Zafar et al., (2017) and Shajib et al., (2017). Air temperature in the study area was found always higher than water temperature except in a few cases. A similar relationship between air and water temperature was also reported by Haldar et al., (1992) in Kaptai lake, Macan (1958), Patra and Azadi (1985) in Halda River. A fluctuating water transparency in different seasons was found due to the inflow of water from hill streams carries suspended matter and silt, which causing this fluctuation. Chowdhury and Mazumder (1981), ARG (1986) and Haldar et al., (1992), also reported the occurrence of fluctuating water transparency in the same. Lower water transparency during monsoon also support the result of Chowdhury and Mazumder (1981), ARG (1986) and Haldar et al., (1992). The higher values of DO occurred was due to the wind action and other surface agitation allowing droppings of maximum oxygen from air to go into solution at the surface water. However, Chowdhury and Mazumder (1981) and Haldar et al., (1992) reported the maximum concentration of oxygen in the winter months which disagrees with present study. The $\mathrm{pH}$ of the lake water was found alkaline range (7.10-7.50). It exhibited a narrow range of 
fluctuation during the study period. Present findings are in close agreement with ARG (1986), Haldar et al., (1992) and Akter et al., (2018) but differ with Chowdhury and Mazumder (1981). The alkalinity or acid combining capacity of impounded waters is generally caused by carbonates and bicarbonates of calcium and magnesium (Rahman et al., 2014). The total alkalinity content in the lake water exhibited a little variation among different seasons (40.00-60.00 ppm) during the course of the present study. Jhingran (1989) observed alkalinity values of more than $50 \mathrm{mg} / \mathrm{l}$ are most productive and those of less than $10 \mathrm{mg} / \mathrm{l}$ do not produce large crops that study also added that total alkalinity values up to $20 \mathrm{mg} / \mathrm{l}$ indicates poor production and values above $40-90 \mathrm{mg} / \mathrm{l}$ shows high production. Accordingly, from the result of present study it may be concluded that Kaptai lake is a productive lake. The present study also observed various water quality (nutrients) parameters such as BOD5 $(10.00 \pm 0.68 \mathrm{mg} / \mathrm{l}), \mathrm{PO}_{4}-\mathrm{P}(3.67 \pm 0.15 \mu \mathrm{g} / \mathrm{l}), \mathrm{NO}_{2}-\mathrm{N}(1.09 \pm 0.19 \mu \mathrm{g} / \mathrm{l}), \mathrm{SiO}_{3}-\mathrm{Si}(0.37 \pm 0.06 \mu \mathrm{g} / \mathrm{l})$, TSS $(0.37 \pm 0.06 \mathrm{~g} / \mathrm{l})$, TDS $(0.39 \pm 0.02 \mathrm{~g} / \mathrm{l})$ and these are important in zooplankton studies. But these parameters are not observed by others in Kaptai lake specifically. Hence, the record of the present study may be helpful for further details study if done in future. A total of four major groups of zooplankton were identified form study area of Kaptai lake from three seasons observation at pre-monsoon, monsoon and Post-monsoon. These four groups are categorized into rotifers, copepods, cladoceras and others (fish larvae, shrimp larvae, insects, mosquito larvae etc.). At the study period it was observed that the mean abundance of group rotifers $103 \mathrm{indv} / \mathrm{l}$, copepods $84.67 \mathrm{indv} / \mathrm{l}$, cladoceras $38.33 \mathrm{indv} / \mathrm{l}$, others $41.83 \mathrm{indv} / \mathrm{l}$. The total percentages of zooplankton composition were rotifers $38 \%$, copepods $32 \%$, cladoceras $14 \%$ and others $16 \%$. The highest group was rotifers in terms of abundance where $38 \%$ were recorded from all three seasons. The lowest group was cladoceras in term of abundance where composition was recorded $14 \%$. ARG (1986) studied on zooplankton in the Kaptai lake extensively and categorized 15 major groups. They recorded, in order of abundance, the overall percentage composition of the total number of zooplankton $\left(94,793 \mathrm{indv} / \mathrm{m}^{3}\right)$ in the lake during the entire study were rotifers $99 \%$, cladocerans $0.9 \%$ and $0.1 \%$ calanoids, miscellaneous insects, chaoborids, cyclopoids, chironomids, may fly larvae, ostracods, water mites, annelids, fish larvae, dragon fly larvae, shrimp larvae and bivalve molluscs. Among them rotifers formed bulk of the zooplankton $\left(93,795 \mathrm{indv} / \mathrm{m}^{3}\right)$ dominating the other groups (only $998 \mathrm{indv} / \mathrm{m}^{3}$ ). The present study on zooplankton at Kaptai lake has some dissimilarities with the study of ARG (1986) in terms of group categorization and composition or percentage of groups. The percentage of rotifer during present study (38\%) was less than the report of ARG (1986) may be due to the degradation of environmental parameters. Barbosa et al. (2014) categorized the zooplankton in three groups (rotifers, copepods, cladoceras) and recorded the composition of those groups as rotifers (57.7\%), copepods (41.0\%), cladoceras (1.3\%). The present study has some similarities with the study of Barbosa et al., (2014) in terms of group categorization and composition of groups. Almost all the lake of the world are dominated by rotifers, copepods and cladoceras. Wetzel (1983) reported that the percentage of production of rotifer, cladoceran, and copepod zooplankton in various lakes around the world, from oligotrophic to eutrophic. The present study on zooplankton at Kaptai lake of Bangladesh has close similarities with the reports of others. However, for better understanding the following table may be represented in support of this amount.

\section{Conclusions}

The zooplankton plays a vital role in aquatic food chain in Kaptai Lake. From the three seasons observation it was recorded that Kaptai Lake is well diversified with zooplankton which gradually increased the fishery resources of the lake. Ultimately the high abundance of zooplankton increases the productivity of lake. During the studied period a total of four major groups of zooplankton were identified from the lake. Among them the percentage of composition of Rotifers, Copepods, Cladocara and others (Insect larvae, Fish larvae, shrimp larvae, mosquito larvae etc.) were higher. Rotifer comprises the highest composition at the lake through whole study which agrees with other reports on lake study.

\section{Conflict of interest}

None to declare.

\section{References}

Akter S, MM Rahman, A Faruk, MNM Bhuiyan, A Hossain and AA Asif, 2018. Qualitative and quantitative analysis of phytoplankton in culture pond of Noakhali district, Bangladesh. Int. J. Fish. Aqua. Stud., 6: 371375.

Akther M, MS Reza, AHMN Jamil and MN Uddin, 2018. Assessment Water Quality and Seasonal Variations Based on Aquatic Biodiversity of Sundarbans Mangrove Forest, Bangladesh. IOSR. J. Biotech. Biochem., 4: 06-15. 
American Public Health Association, 1998. Standard Methods for the Examination of Water and Wastewater. Method 4500 NO2- B, 20th Edition, NW, Washington, D.C. 20005. 4112- 4114 pp.

APHA (American Public Health Association), 1976. Standard methods for the examination of water and waste water. American Public Health Association. Broadway. New York, 10019.

Aquatic Research Group (ARG), 1986. Hydrobiology of Kaptai Reservoir. University Of Chittagong, FAO/UNDP Final report no. DP/BD/79/015-4/FI. 192 pp.

Ayyappan S and TRC Gupta, 1980. Limnology of Ramasamudra Tank. J. Inland. Fish. Soc. India., 12:1-12.

Barbosa PMM, MM Rosa, GFP Diego, LB Sofia, A Akemi and ARB Francisco, 2014. Zooplankton (Copepoda, Rotifera, Cladocera and Protozoa: Amoeba Testacea) from natural lakes of the middle Rio Doce basin, Minas Gerais, Brazil. Biota. Neotrop., 14: e20134040.

Blaber SJM, 2000. Tropical Estuarine Fishes: Ecology, Exploitation and Conservation. Blackwell Science Ltd. $384 \mathrm{pp}$.

Bray JR and JT Curtis, 1957. An ordination of upland forest communities of southern Wisconsin. Ecol. Monograp., 27: 325-349.

Chowdhury SH and A Mazumder, 1981. Limnology of lake Kaptai I. Physico-chemical features. Bangladesh J. Zool., 9: 59-72.

Clarke KR and RM Warwick, 1994.Change in marine communities: an approach to statistical analysis and interpretation. Natural environmental Research Council, Plymouth, UK. 144 pp.

Clarke KR, 1993. Non-parametric multivariate analyses of changes in community structure. Australian. J. Ecol., 18: 117-143.

Das NG, AL Bhuiyan and W Miah, 1982. Taxonomy of calanoid Copepod, Candacia catula (Giesbert) from North-eastern region of the Bay of Bengal. Mahasagar-Bull. National Ins. Ocean., 15: 53-54.

Davis CC, 1955. The Marine and Fresh water plankton. Michigan state University press. Chicago, USA. 562 pp.

DoF (Department of Fisheries), 2010. Fish Fortnight Compendium. Ministry of Fisheries and Livestock. Dhaka, Bangladesh. 13-14. pp.108-109.

Elias SM, 1983. Zooplankton of the Mathamuhuri estuary with special reference to shrimp and finfish larvae. M. Sc. Thesis. IMS, University of Chittagong, BD.

Elser JJ and CR Goldman, 1991. Zooplankton effects on phytoplankton in lakes of contrasting trophic status. Limnol. Oceanogr., 36: 64-90.

EMSL-Ci, 2003. Methods for Chemical Analysis of Water and Wastes. 3rd Edition, Environmental Protection Agency, Cincinnati, Ohio 45268, EPA-600/4-79- 020, Method 354.1, Storet \# Total 00615.

Hach, 2010. Portable Biochemical Oxygen Demand (BOD) Meter Code HQ40D.

Haldar GC, MA Mazid and KK Ahmed, 1992. Limnology and primary production of Kaptai lake, Bangladesh. In: Reservoir Fisheries of Asia (ed. S.S. De Silva). Proceedings of the $2^{\text {nd }}$ Asian reservoir fisheries workshop held in Hangzhou, People's Republic of China, 15-19 October, 1990. IDRC, Ottawa. ON, Canada. IDRC291e. 2-11 pp.

Module HP, 1999. How to measure dissolved, suspended \& total solids: Hydrology Project Training Module; Training module WQ - 10. World Bank \& Government of The Netherlands funded. New Delhi, India. 1-24 pp.

Islam MA, AA Asif, MA Samad, B Sarker, M Ahmed, A Satter and A Hossain, 2017. A comparative study on fish biodiversity with conservation measures of the Bhairabriver, Jessore, Bangladesh. Asian J. Med. Biol. Res., 3: 357-367.

Jhingran AG, 1989. Limnology and production biology of two manmade lakes in Rajasthan (India) with management strategies for their fish yield optimization. Final Report, IDA Fisheries management in Rajasthan, Central Inland capture Fisheries Research Institute Barrackpore, India. 1-63 pp.

Khan AA and AQ Siddique, 1974. Seasonal variations in the limnology of a perennial fish pond at Aligarh. Indian J. Fish., 21: 15-19.

Khan MSA, 1995. Occurrence of Sergestid Shrimp, Lucifers in the Mathamuhuri river of Chakaria Sunderbhans, Bangladesh. M. Sc. Thesis (Unpublished). IMS. Univ. Ctg. 93 pp.

LaMotte Company, 2011. Water Quality Test Kit Instruction Manual, Code 5860-01. 1-18 pp.

Lind DL, 1979. Solar and Terrestrial Noble Gases in Magnetospheric Precipitation. J. Geophy. Res., 84: 64356442.

Macan TT, 1958. The temperature of a small stony stream. Hydrobiologia, 12: 89-106.

Mahmood N, 1990. Study on immigration of commercially penaeid shrimp larvae in the estuarine area of Chakaria, Cox’s Bazar, Bangladesh. PhD Thesis. Department of Zoology. Rajshahi University. 
Mahmood N, YSA Khan and MK Ahmed, 1976. Studies on the hydrology of the Karnafully estuary. J. Asiatic Soc. Bangladesh, 2: 89-99.

Margalef R, 1968. Perspectives in ecological theory. Univ. Chicago Press, Chicago, III. 111 pp.

Mizuno T, 1976. Illustrations of the fresh water plankton of Japan. Hoikusha publishing Co., Ltd. Osaka, Japan, In Japanese. $351 \mathrm{pp}$.

Newell GE and RC Newell, 1979. Marine plankton a practical guide. $5^{\text {th }}$ edition. Hutchinson and Co. Ltd. London. 244 pp.

Patra RWR and MA Azadi, 1985. Limnology of the Halda river. J. Noami., 22: 31-38.

Pielou EC, 1966. The measurement of diversity in different types of biological colledions. J. Theo. Biol., 13: 131-144.

Rahman MM, MA Bashar, Z Farhana and MY Hossain, 2014. Temporal Variation of Physicochemical Parameters in Kaptai Lake, Bangladesh. World J. Fish. Mar. Sci., 6: 475-478.

Santhanam R and A Srinivasan, 1994. Manual of marine zooplankton. Oxford and IBH publishing Co. Pvt. Ltd. New Delhi, Bombay, Calcutta, India. 160 pp.

Shajib MSH, B Sarker, AA Asif, MM Rahman, MA Zafar and A Hossain, 2017. Effects of stocking density on the growth rate of gold fish fry reared in hapa. Asian J. Med. Biol. Res., 3: 504-515.

Shannon CE and W Weaver, 1949. The Mathematical Theory of Communication. University of Illinois Press, Urbana.

Simpson EH, 1949. Measurement of diversity. Nature, 163: 688.

ThermoFisher Scientific Company, 2004. Nitrite Nitrogen Test Kit Method Thermo Orion Method, Code AC2046, 1-12 pp.

ThermoFisher Scientific Company, 2008. Technical Bulletin 517 - Total Alkalinity Measurement in Natural Waters. Code 700010. 1-4 pp.

West WUB, 1973. Fishery Resources of the upper Bay of Bengal. Indian Ocean Programme, Indian Ocean Fisheries Commission, Rome, FAO, IOFC/DEV/73/28. 28 pp.

Wetzel R, 1983. Periphyton of freshwater ecosystems. Develop. Hydrobiol. 17. Dr. W. Junk BV Publ., The Hague. 346 pp.

Whitfield AK, 1999. Ichthyofaunal assemblages in estuaries: A South African case study. Rev. Fish. Biol. Fish., 9: 151-186.

Wickstead JH, 1965. An introduction to the study of tropical plankton. Hutchinson and Co. Ltd. London. 155 pp.

WTW, 2003. Molybdate-vanadate, On-site analyzer P 700 IQ.

Yamazi I, 1950. Plankton investigation in inlet waters along the coast of Japan. I. Introductory notes and the plankton of Akkesi Bay, Hanasaki Inlet and Nemuro Harbour. Pub. Seto Mar. Bioi. Lab. Volume 1.

Zafar M, 1986. Study on Zooplankton of Satkhira in the vicinity of Aquaculture Farms with special reference to Penaeid post larvae. M.Sc. Thesis. IMS. University of Chittagong. BD.

Zafar MA, MZ Hasan, MM Ali and AA Asif, 2017. Growth and production performance of Vietnamese koi (Anabas testudineus) with Magur (Clarias batrachus) at different stocking densities. Asian-Austra. J. Biosci. Biotech., 2: 226-237. 